\title{
Increasing Knowledge of Senior High School Students on Mental Wellbeing and Body Immunity Through Online Counseling
}

\author{
Achmad Iqbal Uswanas ${ }^{\mathrm{a}}$, Alya Anandyta Chairunnisa ${ }^{\mathrm{a}}$, Dini Zulfatus Saniyah ${ }^{\mathrm{a}}$, Jessica \\ Vania Wibowo ${ }^{a}$, Maftuchah Rochmanti ${ }^{\text {* }}$
}

${ }^{a}$ Medical Study Program, Faculty of Medicine, University of Airlangga 60132, Surabaya, Indonesia

${ }^{b}$ Department of Anatomy, Histology, and Pharmacology, Faculty of Medicine, University of Airlangga 60132, Surabaya, Indonesia

${ }^{*}$ Corresponding Author: maftuchah-r@fk.unair.ac.id

\begin{abstract}
During this pandemic, there are many changes in daily activities such as diet, whereas maintaining a balanced diet and nutritious food consumption is very important in increasing immunity and reducing the risk of exposure to infectious diseases. Mental health disorders are also commonly found where the disorder is triggered by various things such as difficulty to meet with friends and family and feeling lonely. However, mental health topic is sometimes still considered taboo due to the lack of education about mental health in Indonesia. To deal with this situation, we took the initiative to conduct education. The purpose of this education is to increase knowledge and awareness in the younger generation regarding the importance of maintaining mental and immunity. The educational activities carried out at senior high school 1 Malang are integrated to support the achievement of the 3rd SDGs. The method used is to provide online counseling, actively involve participants in discussions and questionnaires to determine the level of understanding of high-school students before and after counseling. The results are an increase in student's knowledge about mental health issues and immunity building through balanced nutrition during a pandemic.
\end{abstract}

Keywords: mental health, immune, senior high school, COVID-19 Pandemic, SDGs

\section{Introduction}

Currently COVID-19 pandemic is the most priority challenging worldwide. It is mandatory to attain and maintain good nutritional status to fight against the virus. "An ounce of prevention is worth a pound of cure". Therefore, in unfavorable conditions such as a pandemic that are societies have a risk of exposure to disease, nutrition from food should be the highest priority since the immune system is the only defense mechanism to prevent foreign invasion including viruses. (Aman and Masood, 2020). Immune cells gain a supply of energy supply that is macronutrients and micronutrients act as cofactors in the maintenance immune response (Mishra and Patel, 2020). Individual nutritional status is affected by several factors such as age, gender, health status, lifestyle, and medications (Aman and Masood, 2020). A balanced diet is an important part of maintaining good health by filling the plate with the optimal nutrition to improve the immune system. Moreover, maintaining a proportional weight can also boost the immune system. Therefore, the best way to survive is to strengthen the immune system to fight off the viruses (Birgisdottir, 2020). In addition, various food ingredients are determinants of intestinal microbial composition and further shape the immune response in the body (Mishra and Patel, 2020). Zinc, iron, and vitamins A, B, B6, C, and E are essential for the maintenance of immune function (Aman and Masood, 2020). Individuals who consume a balanced diet will have a good immune system so that it can reduce the incidence of chronic diseases and infections (Kemenkes RI, 2020).

The pandemic has impacted the pattern of daily life. For example, social restrictions or quarantine. It has also brought up several new challenges for individuals to maintain a healthy eating pattern. Prolonged isolation has a greater risk of health, including changes in dietary and sleeps habits, and physical activity (Aman and Masood, 2020). It will increase a sedentary lifestyle that affects physical and mental health. Furthermore, it causes an increased risk of obesity, associated with an increased risk of infection (Adimara et al, 2021). Moreover, Fear and anxiety can also affect poor eating patterns, it even reduces the desire to eat (Sukianto and Marjan, 2020). Therefore, we would like to urge the cities, especially high school students, to understand the importance of understanding a balanced nutritional intake to increase immunity during the COVID-19 pandemic. On the other way, we would also encourage healthy dietary habits of high school students to fight off infectious diseases.

The unprecedented COVID-19 has not only threatened physical health but has also disrupted mental health. Individual psychological reactions play an important role in the occurrence of emotional disturbances during a pandemic. People tend to feel anxious and insecure when environmental changes occur (Kumar et al, 2021). Levels of anxiety and panic increased significantly during the COVID-19 pandemic. This can happen because of the fear of being exposed to disease and getting discriminated against. Social media also plays a huge role. People are influential

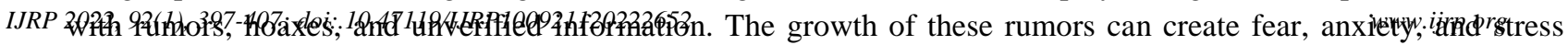
(Kumar et al, 2021). New measures implemented during the pandemic such as self-isolation or quarantine have 
affected routines and activities leading to increased feelings of loneliness, stress, anxiety, cases of depression, insomnia, alcohol, drug use, and self-harm or suicide (WHO, 2012). 2020). Suicide rates increase substantially among those who have persistent negative feelings (Usher et al, 2020).

Throughout the pandemic, anxiety, depression, sleep disruptions, and thoughts of suicide have increased for many young adults. They have experienced several consequences related to the pandemic, such as difficulty meeting friends and family, online schooling, anxiety if exposed to illness, hampered activities, etc. All of these changes can lead to poor mental health. Most young adults (ages 18-24) reported symptoms of anxiety and/or depressive disorders (56\%) as of December 2020 (Panchal et al, 2020). The study also found that drug use (13\%) and suicidal ideation (11\%) were very prominent in young adults. Furthermore, most of them deal with the pandemic by spending more time sleeping and on social media than doing hobbies or exercising. A recent survey by the Indian Psychiatric Society also showed a $20 \%$ increase in mental health since the coronavirus outbreak in India (Kumar et al, 2021). One of the studies with 1210 respondents from 194 cities in China in January and February 2020 found that $54 \%$ of respondents experienced a psychological impact from COVID-19, 29\% reported moderate to severe anxiety symptoms, and 17\% reported moderate to severe depressive symptoms (Cullen et al, 2020). The stigma associated with mental health problems can also lead to an individual reluctance to seek help (Kumar et al, 2021).

Mental health care needs to be developed and implemented. There are several steps to managing mental health to stay positive during a pandemic. First, managing social media consumption by accessing valid information. second, take wise steps in receiving information to protect yourself and your loved ones (WHO, 2020). Third, stay productive by doing activities such as sports. Fourth, find ways to maintain social relationships such as setting up regular phone calls or video calls with family and friends.

As students, we are concerned about the magnitude of the mental health and psychosocial consequences of the pandemic in Indonesia. We provide mental health counseling for societies impacted by COVID-19, especially high school students. It aimed to increase knowledge and awareness of the importance of maintaining mental health. So, they know the symptoms of mental disorders. Moreover, they will understand how to build resilience. All of them will be delivered by video conference, Zoom. This step is expected to help to reduce the number of mental disorders or prevent morbidity due to mental illness.

Based on these two problems, we as Airlangga University students provide a solution to conducting health education through the Real Work Lecture (KKN) program in achieving the SDGs (sustainable development goal). In accordance with the 3rd SDGs program out of 17 goals is to ensure healthy lives and encourage welfare at all ages. The increased understanding is expected to be practiced by students in daily activities. So that they can maintain physical health during the pandemic by increasing immunity through balanced nutrition. Moreover, they can maintain mental health by building good resilience.

\section{Method}

This activity is a community service activity carried out based on ongoing problems, namely the impact of the Coronavirus Disease-19 (COVID-19) pandemic on body immunity and mental health. The solutions offered by the Institute for Community Service and Development and the Faculty of Medicine Group 20 of Community ServiceCovid-19 Online Modules Airlangga University are Web Seminars (Webinar), educational posters, and health counseling.

Activities in the form of counseling are carried out on Wednesday, July 14, 2021 and Thursday, July 15, 2021 through the google meet platform. This activity was carried out in several stages, including preparation, implementation, and evaluation of activities. The preparation was started by formation of a plan for counseling activities, forming a committee, distribution of job descriptions for the committee, and licensing for the target participants (Senior High School 1 Malang). The counseling topics given were "The Role of Nutrition and Lifestyle in Optimizing Body's Immunity to Fight COVID-19" and "How to Maintain Positive Vibes in Daily Life".

Coordination with State Senior High School 1 Malang was carried out to support this activity with a total of 265 students consisting of second and third grade. The counseling activity on Wednesday, July 14, 2021 was carried out in 2 sessions. Meanwhile, the counseling activities on Thursday, July 15, 2021 were carried out in 10 sessions. The average number of participants in one session was 22 students. Each session got one of the two counseling topics. The activity was started with an opening along with handing out the pre-test form to the participants. The pre-test form given was 5 questions from one of the two counseling topics. After that proceed with the delivery of the material to the participants. A question and answer session was held for the participants along with the provision of a post-test form as the closing session of the counseling. The five questions on the post-test form are the same as the pre-test form. After that, they were given a few minutes outside the counseling time to provide an introduction hwo University and the Faculty of Medicine, Airlangga University. 
Observations were made during the counseling by observing the activeness of the participants in the question and answer session. An evaluation was done by assessing the increase in knowledge through pre-test and post-test evaluations related to the material given. The evaluation stage was making and submitting reports on the results of training activities. The evaluation was conducted to determine the participant's response to the implementation of this counseling activity on the level of understanding and participation.

\section{Result and Discussion}

Based on the results of the pre-test and post-test evaluations that were carried out before and after the counseling was carried out, it was found that there was an increase in students of senior high school 1 Malang understanding of mental health and body immunity. The following are the results of the pre-test and post-test analysis regarding mental health

Table 1. Frequency Distribution of Mental Health Pre-Test and Post-Test Answers

\begin{tabular}{|c|c|c|c|c|c|c|c|c|c|}
\hline \multirow[t]{2}{*}{ No } & \multirow[t]{2}{*}{ Question } & \multicolumn{4}{|c|}{ Frequency of Correct Answers } & \multicolumn{4}{|c|}{ Frequency of Wrong Answers } \\
\hline & & $\begin{array}{l}\text { Pre- } \\
\text { Test }\end{array}$ & $\%$ & $\begin{array}{l}\text { Post- } \\
\text { Test }\end{array}$ & $\%$ & $\begin{array}{l}\text { Pre- } \\
\text { Test }\end{array}$ & $\%$ & $\begin{array}{l}\text { Post- } \\
\text { Test }\end{array}$ & $\%$ \\
\hline 1 & $\begin{array}{l}\text { Loss of interest and excitement, } \\
\text { having trouble sleeping, feeling } \\
\text { useless, reduced concentration, } \\
\text { energy and self-esteem are } \\
\text { characteristics of }\end{array}$ & 100 & 76,9 & 124 & 95,4 & 30 & 23,1 & 6 & 4,6 \\
\hline 2 & $\begin{array}{l}\text { Excessive autonomic activity } \\
\text { (sweating, shortness of breath, } \\
\text { dizziness, etc.), motor tension } \\
\text { (restlessness, shaking), } \\
\text { excessive worry, difficulty } \\
\text { concentration is a } \\
\text { characteristic of }\end{array}$ & 45 & 34,6 & 121 & 93,1 & 85 & 65,4 & 9 & 6,9 \\
\hline 3 & $\begin{array}{l}\text { Unable to stay away or avoid } \\
\text { the desired activity or thing, } \\
\text { unable to stop using or doing } \\
\text { something, not being able to } \\
\text { control oneself over what one } \\
\text { wants, and ignoring the bad } \\
\text { effects that may occur are } \\
\text { characteristics from }\end{array}$ & 96 & 73,8 & 125 & 96,2 & 34 & 26,2 & 5 & 3,8 \\
\hline 4 & $\begin{array}{l}\text { A true statement about mental } \\
\text { health is }\end{array}$ & 129 & 99,2 & 130 & 100 & 1 & 0,8 & 0 & 0 \\
\hline 5 & $\begin{array}{l}\text { The following option is a } \\
\text { treatment for mental health } \\
\text { problems, except }\end{array}$ & 124 & 95,4 & 130 & 100 & 6 & 4,6 & 0 & 0 \\
\hline
\end{tabular}


On mental health learning materials, 130 students of class XI and XII participated in the counseling and conducted pre-test and post-test. The first, second, and third questions are questions that discuss the characteristics of any types of mental health. From the results of the pre-test, the first question was answered correctly by 100 students, the second question was answered correctly by 45 students, and the third question was answered correctly by 96 students. In the post-test, the first question was answered correctly by 124 students, the second question was answered correctly by 121 students, and the third question was answered correctly by 125 students. The first question was not answered correctly by $23.1 \%$ of all students on the pre-test and $4.6 \%$ of the students in the post-test were not answered correctly. The second question was not answered correctly by $65.4 \%$ of all students in the pre-test and $6.9 \%$ of the students were not answered correctly in the post-test. The third question was not answered correctly by $26.2 \%$ of all students in the pre-test and 3.8\% of the students in the post-test were not answered correctly. This shows that there is an increase in student's understanding of the types of mental health and being able to distinguish between these types.

The fourth question was answered correctly by 129 students in the pre-test and 130 students answered correctly in the post-test. The fifth question was answered correctly by 124 students in the pre-test and all students answered correctly in the post-test. The fourth question was not answered correctly by $0.8 \%$ of all students in the pre-test and the fifth question was not answered correctly by $4.6 \%$ of all students in the post-test. Based on the data above, it can be concluded that there is an increase in student's knowledge about mental health facts and how to treat mental health.

Table 2. Wilcoxon Ranks Test Results on Mental Health Pre-Test and Post-Test

\begin{tabular}{clccc}
\hline & & $\mathrm{N}$ & $\begin{array}{r}\text { Mean } \\
\text { Rank }\end{array}$ & $\begin{array}{c}\text { Sum of } \\
\text { Ranks }\end{array}$ \\
\hline $\begin{array}{c}\text { Mental health Post- } \\
\text { test and Pre-test }\end{array}$ & $\begin{array}{l}\text { Negative } \\
\text { Ranks }\end{array}$ & 3 & 47.83 & 143.50 \\
\cline { 2 - 5 } & $\begin{array}{l}\text { Positive } \\
\text { Ranks }\end{array}$ & 85 & 44.38 & 3772.50 \\
\cline { 2 - 5 } & Ties & 42 & & \\
\cline { 2 - 4 } & Total & 130 & & \\
\hline
\end{tabular}

Table 3. Percentage of Differences in Mental Health Pre-Test and Post-Test Scores

\begin{tabular}{ccc}
\hline $\begin{array}{c}\text { Changes in mental health pre-test and } \\
\text { post-test scores }\end{array}$ & Total & Percentage (\%) \\
\hline Decrease & 3 & 2,3 \\
\hline Increase & 85 & 65,4 \\
\hline Same & 42 & 32,3 \\
\hline Total & 130 & 100 \\
\hline
\end{tabular}

Based on the Wilcoxon test results listed in table 2, the results of the negative ranks were obtained for 3 students with a percentage of $2.3 \%$ (table 3). Negative ranks indicate that the student's post-test results are lower than their pre-test scores. While the positive ranks indicate that the participant's post-test scores are higher than the pre-test scores. So it was found that 85 students who took part in counseling activities on mental health experienced an increase in knowledge with a percentage of $65.4 \%$. In addition, the ties value was also obtained at 42 which indicated that there was no change in the value of the pre-test and post-test that had been done. It can be concluded that the 42 students got the same score between the pre-test and post-test with a percentage of $32.3 \%$. 
Table 4. Table of Wilcoxon Test Statistics Test

\begin{tabular}{lr}
\hline & \multicolumn{2}{c}{$\begin{array}{c}\text { postest mental - } \\
\text { pretest mental }\end{array}$} \\
\hline $\mathrm{Z}$ & -7.718 \\
\hline Asymp. Sig. (2-tailed) & 0.000 \\
\hline
\end{tabular}

Based on the output of statistical test data on the Wilcoxon test contained in table 4, it is known that the value of Asymp.Sig. (2-tailed) of 0.000 . Because the value of 0.000 is smaller than 0.05 , it can be interpreted that there is a difference in the scores on the student's pre-test and post-test and it can be concluded that there is an increase in student's knowledge between before and after counseling on mental health.

Table 5. Table of a frequency distribution of Mental Health Pre-Test scores

\begin{tabular}{cccc}
\hline Question Number & Frequency & Percentage (\%) & 0.8 \\
\hline 1 & 1 & 12.3 \\
\hline 2 & 16 & 23.8 \\
\hline 3 & 31 & 32.3 \\
\hline 4 & 42 & 30.8 \\
\hline 5 & 40 & 100 \\
\hline
\end{tabular}

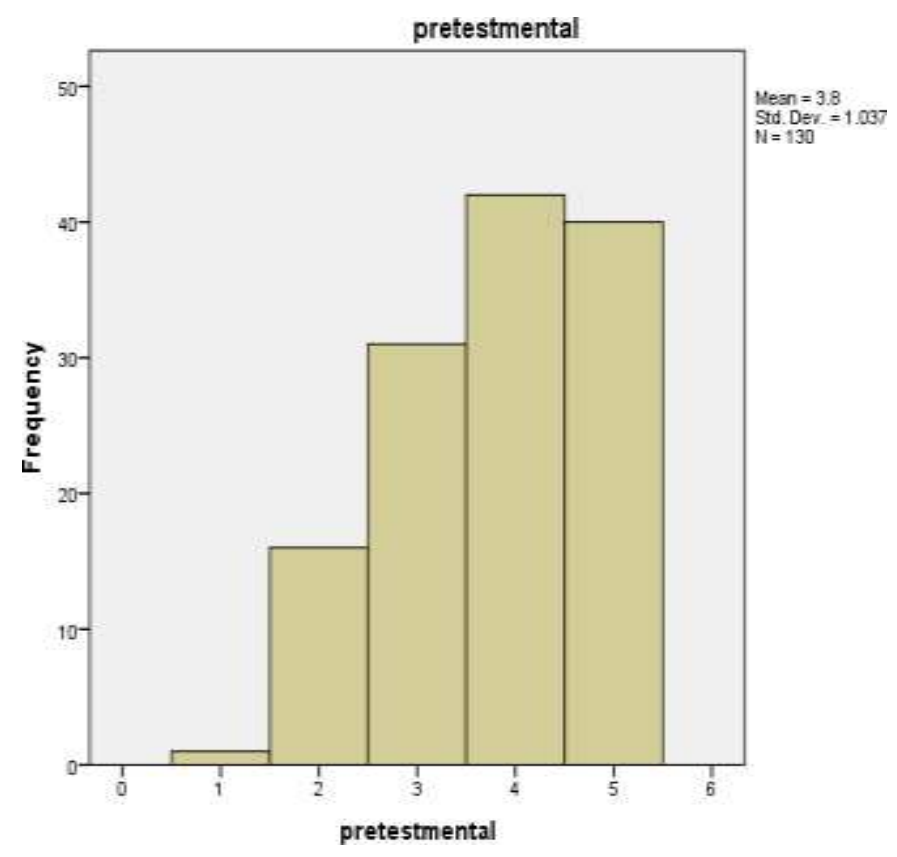

Figure 1. Frequency distribution diagram of Mental Health Pre-Test scores

Table 6. Table of a frequency distribution of Mental Health Post-Test scores

\begin{tabular}{cccc}
\hline Question Number & Frequency & Percentage $(\%)$ & 0 \\
\hline 1 & 0 & .8 \\
\hline 2 & 1 & 2.3 & 8.5 \\
\hline 3 & 3 & 88.5 \\
\hline 4 & 11 & 115 & 100 \\
\hline 5 & 164 & www.ijrp.org
\end{tabular}




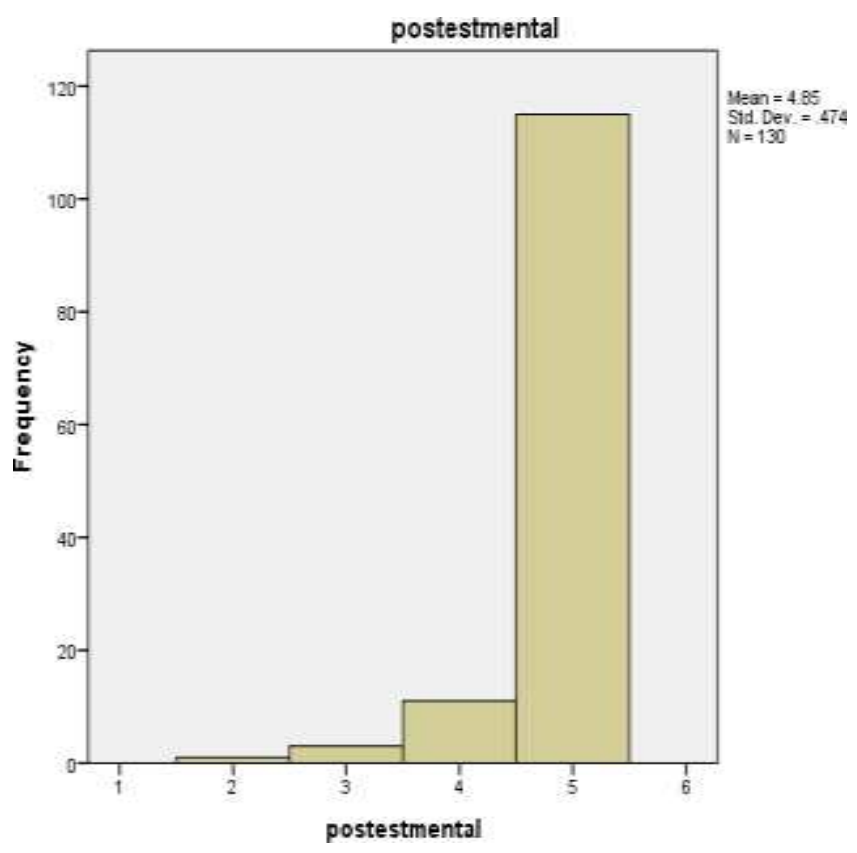

Figure 2. Frequency distribution diagram of Mental Health Post-Test scores

Based on table 5 and figure 1, it was found that the number of students with pre-test scores with the highest mental health topic was a score of 4, which was 42 students. After counseling, based on table 6 and figure 2, it was found that the number of students with post-test scores with the highest mental health topic was a score of 5 , which was 115 students.

Table 7. Table of Average Pre-Test and Post-Test Mental Health Scores

\begin{tabular}{cc}
\hline \multicolumn{2}{c}{ Average } \\
\hline Mental Health Pre-Test & Mental Health Post-Test \\
\hline 3,80 & 4,85 \\
\hline
\end{tabular}

Based on table 7, it can be seen that there was an increase in the average pre-test score towards the posttest score, where the average pre-test score was 3.80 and the post-test average score was 4.85 .

The following table is a pre-test and post-test analysis regarding increasing body immunity through the fulfillment of balanced nutrition during the pandemic.

Table 8. Frequency Distribution of Body Immunity Pre-Test and Post-Test Answers

\begin{tabular}{|c|c|c|c|c|c|c|c|c|c|}
\hline \multirow[t]{2}{*}{ No } & \multirow[t]{2}{*}{ Question } & \multicolumn{4}{|c|}{ Frequency of Correct Answers } & \multicolumn{4}{|c|}{ Frequency of Wrong Answers } \\
\hline & & $\begin{array}{l}\text { Pre- } \\
\text { Test }\end{array}$ & $\%$ & $\begin{array}{l}\text { Post- } \\
\text { Test }\end{array}$ & $\%$ & $\begin{array}{l}\text { Pre- } \\
\text { Test }\end{array}$ & $\%$ & $\begin{array}{l}\text { Post- } \\
\text { Test }\end{array}$ & $\%$ \\
\hline 1 & $\begin{array}{l}\text { Eggs, meat, fish, tofu, } \\
\text { tempeh, and nuts are a lot } \\
\text { of food that contain... }\end{array}$ & 164 & 100 & 164 & 100 & 0 & 0 & 0 & 0 \\
\hline 2 & $\begin{array}{l}\text { Nutrients that play an } \\
\text { important role in } \\
\text { increasing and } \\
\text { maintaining the } \\
\text { body's immune } \\
\text { system is }\end{array}$ & 157 & 95,7 & 159 & 97 & 7 & 4,3 & 5 & 3 \\
\hline 3 & $\begin{array}{l}\text { How much water must be } \\
\text { filled in a day? }\end{array}$ & 140 & 85,4 & 154 & 94 & 24 & 14,6 & 10 & 6 \\
\hline
\end{tabular}




\begin{tabular}{|c|c|c|c|c|c|c|c|c|c|}
\hline 4 & $\begin{array}{l}\text { A } 23 \text {-year-old woman } \\
\text { with BMI (Body Mass } \\
\text { Index) }=28 \mathrm{~kg} / \mathrm{m} 2 . \mathrm{In} \\
\text { which weight category } \\
\text { does this woman belong? }\end{array}$ & 32 & 19,5 & 125 & 76,2 & 132 & 80,5 & 39 & 23,8 \\
\hline 5 & $\begin{array}{l}\text { The following are things } \\
\text { that need to be done to } \\
\text { increase immunity during } \\
\text { a pandemic, except }\end{array}$ & 131 & 79,9 & 153 & 93,3 & 33 & 20,1 & 11 & 6,7 \\
\hline
\end{tabular}

On the learning material about increasing body immunity through the fulfillment of balanced nutrition, the counseling was attended by 164 students of class XI and XII and carried out pre-test and post-test. From the results of the pre-test and post-test, the first question was answered correctly by all students so that it can be concluded that all students have a good understanding of the types of foods that contain protein. The second question was answered correctly by 157 students in the pre-test and correctly answered by 159 students in the post-test. The second question was not answered correctly by $4.3 \%$ of all students in the pre-test question and was not answered correctly by $3 \%$ of the participating students in the post-test question. This shows that there is an increase in students understanding of the types of nutrients that play an important role in improving the body's immune system. The third question was answered correctly by 140 students in the pre-test and was answered correctly by 154 students in the post-test. The third question was not answered correctly by $14.6 \%$ of all students in the pre-test question and was not answered correctly by $6 \%$ of the participating students in the post-test question. This shows that there is an increase in student's understanding of the amount of water needed by the body in a day. The fourth question was answered correctly by 32 students in the pre-test and 125 students answered correctly in the post-test. The fourth question was not answered correctly by $80.5 \%$ of all students in the pre-test and $23.8 \%$ of the students in the post-test were not answered correctly. With this, it can be concluded that there is a significant increase in student's knowledge of body mass index. The fifth question was answered correctly by 131 students on the pre-test questions and correctly answered by 153 students on the post-test questions. The fifth question was not answered correctly by $20.1 \%$ of all students in the pre-test and the fifth question was not answered correctly by $6.7 \%$ of all students in the post-test. This shows that there is an increase in knowledge about the fulfillment of body nutrition to increase immunity during a pandemic.

Table 9. Wilcoxon Ranks Test Results on Pre-Test and Post-Test about Immunity

\begin{tabular}{|c|c|c|c|c|}
\hline & & $\mathrm{N}$ & $\begin{array}{l}\text { Mean } \\
\text { Rank }\end{array}$ & $\begin{array}{l}\text { Sum of } \\
\text { Ranks }\end{array}$ \\
\hline \multirow[t]{4}{*}{$\begin{array}{l}\text { postestimmune - } \\
\text { pretestimmune }\end{array}$} & $\begin{array}{l}\text { Negative } \\
\text { Ranks }\end{array}$ & 14 & 52.32 & 732.50 \\
\hline & $\begin{array}{l}\text { Positive } \\
\text { Ranks }\end{array}$ & 111 & 64.35 & 7142.50 \\
\hline & Ties & 39 & & \\
\hline & Total & 164 & & \\
\hline
\end{tabular}


Table 10. Percentage of Differences in Pre-Test and Post-Test about Immunity

\begin{tabular}{ccc}
\hline $\begin{array}{c}\text { Changes in body immunity pre-test and } \\
\text { post-test scores }\end{array}$ & Total & Percentage (\%) \\
\hline Decrease & 14 & 8,5 \\
\hline Increase & 111 & 67,7 \\
\hline Same & 39 & 23,8 \\
\hline Total & 164 & 100 \\
\hline
\end{tabular}

Based on the results of the Wilcoxon test to challenge the pre-test and post-test of immunity listed in table 9, the results obtained are negative ranks for 14 students with a percentage of $8.5 \%$ (table 10). Furthermore, it was found that 111 students who took part in counseling activities regarding increasing body immunity through nutritional fulfillment experienced an increase in knowledge with a percentage of $67.7 \%$. In addition, the ties value is 39 with a percentage of $23.8 \%$. From table 9, it can be interpreted that there are 14 students with post-test scores lower than pre-test scores, 111 students with post-test scores higher than pre-test scores, and 39 students getting the same score between pre-test and post-test.

Table 11. Table of Wilcoxon Test Statistics Test

\begin{tabular}{lcc}
\hline & $\begin{array}{c}\text { postestimun - } \\
\text { pretestimun }\end{array}$ \\
\hline $\mathrm{Z}$ & & -8.374 \\
\hline Asymp. Sig. (2- tailed) & & 0.000 \\
\hline
\end{tabular}

Based on the output of statistical test data in the Wilcoxon test contained in table 11, it is known that the value of Asymp.Sig. (2-tailed) of 0.000 . So it can be interpreted that there is a difference in the scores on the students' pretest and post-test and it can be interpreted that there is an increase in students' knowledge between before and after counseling about increasing body immunity through nutritional fulfillment during the COVID-19 pandemic.

Table 12. Table of a frequency distribution of Pre-Test Immunity scores

\begin{tabular}{ccc}
\hline Question Number & Frequency & Percentage $(\%)$ \\
\hline 1 & 0 & 0 \\
\hline 2 & 8 & 4.9 \\
\hline 3 & 38 & 23.2 \\
\hline 4 & 96 & 58.5 \\
\hline 5 & 22 & 13.4 \\
\hline Total & 164 & 100 \\
\hline
\end{tabular}




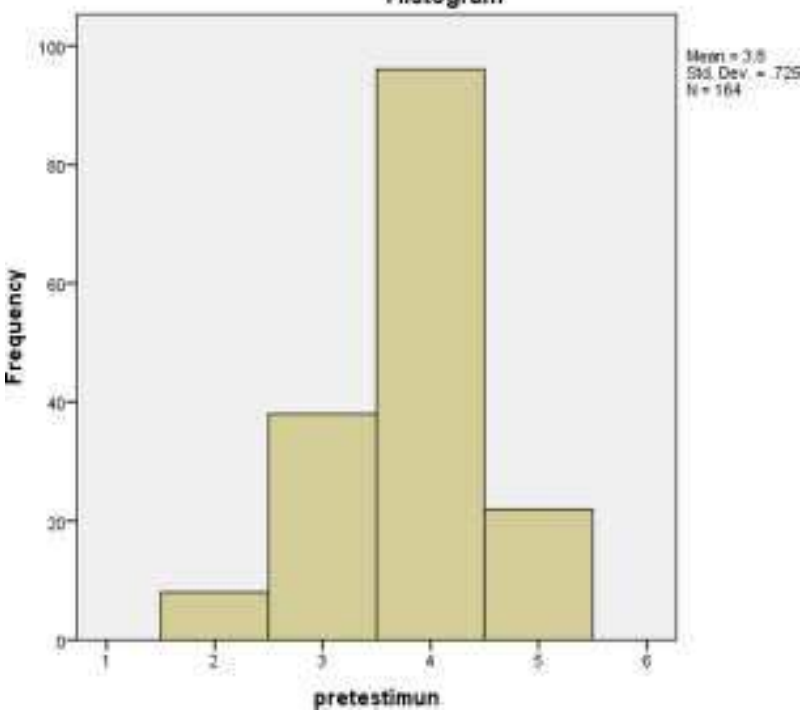

Figure 3. Frequency distribution diagram of the Pre-Test Immunity

Table 13. Table of a frequency distribution of Post-Test Immunity scores

\begin{tabular}{ccc}
\hline Question Number & Frequency & Percentage $(\%)$ \\
\hline 1 & 0 & 0 \\
\hline 2 & 2 & 1.2 \\
\hline 3 & 11 & 6.7 \\
\hline 4 & 39 & 23.8 \\
\hline 5 & 112 & 68.3 \\
\hline Total & 164 & 100 \\
\hline
\end{tabular}

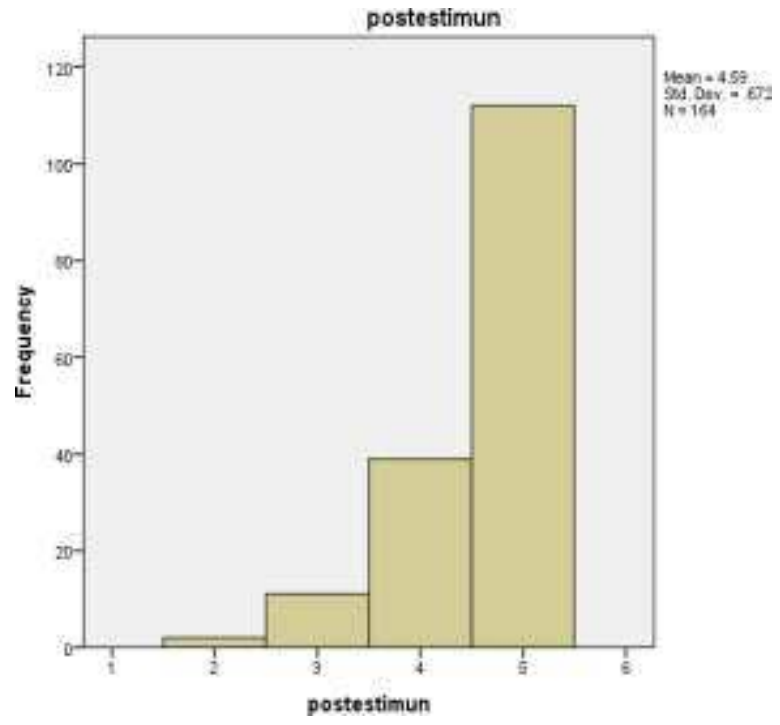

Figure 4. Frequency distribution diagram of Post-Test Immunity scores. 
Based on Table 12 and Figure 3, it is found that the number of students with pre-test scores with the topic of immunity the most is a score of 4 which is equal to 96 students. After counseling, based on table 13 and Figure 4, the number of students obtained with a post-test score with the highest topic of immunity was a score of 5 , which was 112 students.

Table 14. Table of Average Pre-Test and Post-Test Immunity Scores

\begin{tabular}{cc}
\hline \multicolumn{2}{c}{ Average } \\
\hline Immunity Pre-Test & Immunity Post-Test \\
\hline 3,80 & 4,59 \\
\hline
\end{tabular}

Based on table 14, it can be seen that there was an increase in the average pre-test score towards the post-test score, where the average pre-test score was 3.80 and the post-test average score was 4.59.

Based on the results of the pre-test, post-test during the activity, this community service activity gave the following results:

1) Increasing student's knowledge and understanding of the importance of mental health during the COVID-19 pandemic.

2) Increasing student's knowledge and understanding of the importance of maintaining body immunity during the COVID-19 pandemic.

A study on Public Health Nutrition Students in Norway stated that the sudden switch to online education methods during the COVID-19 pandemic made it difficult for 50\% of students to achieve maximum learning outcomes (Almendingen et. al, 2021). In addition, a study in Pakistan showed $65.4 \%$ of respondents had less knowledge about COVID-19 (Ali et. al, 2021). During the COVID-19 pandemic, there has been an increasing dependence on social media to find information about COVID-19. However, this information was not confirmed by health professionals. This can be an evaluation for health professionals in adapting to the development of health information delivery methods. Proactive cooperation, institutional support, and effective training need to be carried out as an effort to prevent the spread of misinformation during the COVID19 pandemic (Neely et al, 2021).

The implementation of community service at Senior High School 1 Malang went well and smoothly. This counseling is aimed at Senior High School 1 Malang students, namely by presenting the material carried out by the resource persons, it is hoped that with this counseling students have additional knowledge and understanding of students about the importance of mental health and the importance of maintaining body immunity during the COVID-19 pandemic. Based on the evaluation of its implementation, it can be identified the supporting factors of this activity so that it can run well and smoothly with the support of the Counseling Guidance teacher at Senior High School 1 Malang. While the inhibiting factors of this activity were the limited time available in providing counseling so that there was no time for interactive question and answer sessions with participants, several times there were signal problems so that the voice faltered, and the implementation time was delayed once because the class had not started and participants not ready.

\section{Conclusions}

Online education activities carried out for senior high school students, are effective in increasing the 
understanding of high school students about the importance of mental health and body immunity through fulfilling nutrition, especially during the current COVID-19 pandemic. With the implementation of this activity, there is an increase in knowledge of mental health and an increase in body immunity, as evidenced by the increase in the evaluation scores of the pre-test and post-test indicating that the student's knowledge is increasing. Community service for a young age is still very important to improve the quality of mental health and body immunity through good nutrition during the COVID-19 pandemic in the East Java region and throughout Indonesia.

\section{Acknowledgements}

We would like to thank Mr. Agus, Mrs. Istin, and Mr. Ardi, as Counseling Guidance (BK) teachers at SMAN 1 Malang and all students at SMAN 1 Malang, as participants in this study for their assistance in facilitating this community service activity.

\section{References}

Adimara, A., Prahasanti, K., and Airlangga, M. P. (2021). Pengaruh Peningkatan Jaringan Adiposa pada Pasien Obesitas Terhadap Tingkat Keparahan Pasien Covid-19. Jurnal Ilmiah Kedokteran Wijaya Kusuma, 10(2), 222-242. Retrieved from https://journal.uwks.ac.id/index.php/jikw/article/view/1453/pdf

Ali, R., Jawed, S., Baig, M., Azam Malik, A., Syed, F., and Rehman, R. (2021). General Public Perception of Social Media, Impact of COVID-19 Pandemic, and Related Misconceptions. Disaster Medicine and Public Health Preparedness, 1-8. DOI:10.1017/dmp.2021.229

Almendingen, K., Morseth, M.S., Gjølstad, E., Brevik, A., and Tørris, C. (2021). Student's experiences with online teaching following COVID-19 lockdown: A mixed methods explorative study. PLOS ONE, 16(8). DOI: 10.1371/journal.pone.0250378

Aman, F. and Masood, S. (2020). How Nutrition can help to fight against COVID-19 Pandemic. Pakistan Journal of Medical Sciences, 36(COVID19-S4), p.S121. DOI: 10.12669/pjms.36.COVID19-S4.2776

Birgisdottir, B.E. (2020). Nutrition is key to global pandemic resilience. BMJ Nutrition, Prevention \& Health, $3(2)$, p.129. DOI:10.1136/bmjnph-2020-000160

Cullen, W., Gulati, G., and Kelly, B.D. (2020). Mental health in the COVID-19 pandemic. QJM: An International Journal of Medicine, 113(5), pp.311-312. DOI: 10.1093/qjmed/hcaa110

Kemenkes RI. (2020). Panduan Gizi Seimbang pada Masa Pandemi COVID-19 "Lindungi Keluarga”. Indonesia: Kementerian Kesehatan RI.

Kumar, A. and Nayar, K.R. (2021). COVID 19 and its mental health consequences. J Mental Health, 30(1). DOI: $10.1080 / 09638237.2020 .1757052$

Mishra, S. and Patel, M. (2020). Role of nutrition on immune system during COVID-19 pandemic. J Food Nutr Health 2020, 3(2). Retrieved from https://www.researchgate.net/publication/344542095_role-of-nutrition-on-immune-system-during-covid19pandemic-3

Neely, S., Eldredge, C., and Sanders, R. (2021). Health Information Seeking Behaviors on Social Media During the COVID-19 Pandemic Among American Social Networking Site Users: Survey Study. J Med Internet Res, 23(6), DOI: 10.2196/29802

Panchal, N., Kamal, R., Orgera, K., Cox, C., Garfield, R., Hamel, L., and Chidambaram, P. (2020). The implications of COVID-19 for mental health and substance use. Kaiser family foundation, 21. Retrieved from https://www.kff.org/health-reform/issue-brief/theimplications-of-covid-19-for-mental-health-and-substance-use/

Sukianto, R. E. and Marjan, A. Q. (2020). Hubungan tingkat stres, emotional eating, aktivitas fisik, dan persen lemak tubuh dengan status gizi pegawai Universitas Pembangunan Nasional Jakarta. Ilmu Gizi Indonesia, 3(2), 113-122. Retrieved from http://ilgi.respati.ac.id/index.php/ilgi2017/article/view/135

Usher, K., Durkin, J., and Bhullar, N. (2020). The COVID-19 pandemic and mental health impacts. International Journal of Mental Health Nursing, 29(3), p.315. DOI: 10.1111/inm.12726

World Health Organization. (2020). Mental health and psychosocial considerations during the COVID-19 outbreak. Geneva, Switzerland: World Health Organization 